\title{
The Effect of Social Capital on Social Entrepreneurial Intention among Vietnamese Students*
}

\author{
Ngoc Thang HA ${ }^{1}$, Xuan Hau DOAN ${ }^{2}$, Trong Nghia VU ${ }^{3}$, Thi Phuong Linh NGUYEN ${ }^{4}$, \\ Thanh Hoa PHAN ${ }^{5}$, Cong Doanh DUONG ${ }^{6}$
}

Received: April 10, 2020 Revised: May 03, 2020 Accepted: July 11, 2020

\begin{abstract}
This study develops the model to estimate the links between social capital, social entrepreneurial self-efficacy, perceived desirability and social entrepreneurial intention. Besides exploring the direct impacts of social capital, social entrepreneurial self-efficacy, and perceived desirability on social entrepreneurial intention, this study also focus on discovering the mediating roles of perceived desirability and social entrepreneurial self-efficacy on this relationship. Throughout adopting measures from some previous studies, the authors design the questionnaires and distribute to students in Vietnam. The study presents some demographic information of 289 students, who are studying at university and colleges in Vietnam. Then, the validity and reliability of scales are assessed using the value of Cronbach's alpha, Exploratory Factor Analysis (EFA) and Confirmatory Factor Analysis (CFA). In addition, by utilizing the structural modeling structure (SEM), the authors show that social capital plays the important role in shaping social entrepreneurial self-efficacy, perceived desirability, and social entrepreneurial intention. Interestingly, besides the direct effects on social entrepreneurial intention, perceived desirability and social entrepreneurial self-efficacy also mediate the correlation between social capital and social entrepreneurial intention. Also, with the interesting findings of the study, the authors propose several recommendations for policy-makers, educators and academics to promote the social entrepreneurship and innovation among Vietnamese students.
\end{abstract}

Keywords: Social Capital, Perceived Desirability, Social Entrepreneurial Self-Efficacy, Social Entrepreneurial Intention

JEL Classification Code: L26, L31, M10

${ }^{1}$ First Author. Lecturer, Department of General Management, Faculty of Business Management, National Economics University, Vietnam. Email: hangocthang@yahoo.com

'Lecturer, Department of Enterprise Management, Faculty of Business Management, National Economics University, Vietnam.

Email: haudoanxuan.neu@gmail.com

${ }^{3} \mathrm{Head}$ of Communication Department, National Economics

University, Vietnam. Email: trongnghiavu76@yahoo.com.vn

${ }^{4}$ Lecturer, Department of General Management, Faculty of Business

Management, National Economics University, Vietnam.

Email: plinhkt@gmail.com

${ }^{5}$ Lecturer, Department of General Management, Faculty of Business

Management, National Economics University, Vietnam.

Email: ptthlh@yahoo.com

${ }^{6}$ Corresponding Author. Lecturer, Department of General Management, Faculty of Business Management, National Economics University, Vietnam [Postal Address: 1940 HH2B, Linh Dam, Hoang Mai, Hanoi, 100000, Vietnam]

Email: doanhdc@neu.edu.vn

(c) Copyright: The Author(s)

This is an Open Access article distributed under the terms of the Creative Commons Attribution Non-Commercial License (http://Creativecommons.org/licenses/by-nc/4.0/) which permits unrestricted noncommercial use, distribution, and reproduction in any medium, provided the original work is properly cited.

\section{Introduction}

Although there is a predominant concentration on 'wealth creation' as a perspective in entrepreneurship study (Welter et al., 2017), the increase of new streams of requirements that evaluate the social value-added role of entrepreneurship is now looked at (Chandra, 2017; Zahra \& Wright, 2016). Thus, the concept of social entrepreneurship increasingly attracts the attention of both academics and practitioners (Canestrino et al., 2020), as presented by a growing body of theoretical literature and by the growth of both new scientific and nonscientific communities as well (Dwivedi \& Weerawardena, 2018; Rey-Martí et al., 2016). Because of the fast rise of this phenomenon, emerging research is emphasizing the necessity of new theoretical and practical contributions. However, social entrepreneurship is still characterized by a lack of theoretical frontiers, and is also challenged by contesting definitions and conceptual framework as well as existing gaps in the literature and restricted empirical studies (Canestrino et al., 2020; Rey-Marti et al., 2016). 
Social entrepreneurship builds innovative solutions to immediate social issues and mobilizes the ideas, abilities, resources, and social arrangements needed for sustainable social transformation (Alvord et al., 2004). Also, sociallyentrepreneurial activities with its focus on social problemsolving and innovation not only blur the traditional frontiers between the public, private and non-profit field, they also accentuate hybrid models for profit and non-profit business (Johnson, 2003). Social entrepreneurship that borrows the scheme from the world of business is becoming more and more popular (Anh \& Harald, 2016). Social entrepreneurs are defined as individuals who employs business principles and even capitalism itself to change the social conditions by creating and managing a business venture (Durieux \& Stebbins, 2010), whereas social entrepreneurship aims to create social value or deal with social problems by innovative solutions. It is also seen as the clear and central point of social entrepreneurship and distinguishes social entrepreneurship from other forms of entrepreneurship (Austin et al., 2006; Peredo \& McLean, 2005). Thus, social entrepreneurship has explicitly been the concept involved in business, society and politics (Anh \& Korflesch, 2016), it is also understood as the triple bottom line, which consists of social, financial and environmental aspects (Robinson, 2006).

The rise of entrepreneurship depends on both quality and quantity of entrepreneurs (Acs \& Audretsch, 2003). The more entrepreneurial intention grows up; the more entrepreneurs appear in our society. In other words, intentions are still perceived as the single best predictors of behavior (Ajzen, 1991), including entrepreneurial behavior (Krueger, 2000; Linan et al., 2011, Lee \& Kim, 2019). Entrepreneurial intention is also seen as a cognitive process that orients and directs a person' planning and applying this business plan (Boyz \& Vozikis, 1994; Luc, 2018; Lu \& Wang, 2018). Thus, the approach of developing a model which can explore the formation of people' intention to run their own business can be reasonable, significant and appropriate in the case of social entrepreneurship so far society. However, it is emphasized that little is understood about the intention of entrepreneurs in the social matter of business venturing (Anh \& Korflesch, 2016).

Besides, entrepreneurship is not only seen as an economic phenomenon, but it is also determined as a social one. Thus, social perspectives are often interested in entrepreneurship researches via some concepts such as social capital, social network, cognitive capital and human capital (Vuković et al., 2017). Indeed, the important role of social capital on forming business start-up intention has been determined in much research, but almost previous researches consider that the concept of social capital either is similarly to human capital or cognitive capital. Indeed, social capital is seen as a network of relationship that has economic benefits such as opportunities, resources and goodwill (Arregle et al., 2007; Agbim, 2019); it reflects both financial and non-financial support from family and friends (Davidsson \& Honig, 2003). With the support of friends and family, people may have positive perceived desirability towards entrepreneurship, entrepreneurial self-efficacy, and entrepreneurial intention. In this study, we examine the relationship between social capital, perceived feasibility, entrepreneurial self-efficacy, and entrepreneurial intention in the context of social business ventures. Particularly, our study aims to test the direct effects of social capital on social entrepreneurial self-efficacy, perceived desirability, and social entrepreneurial intention. In addition, the mediating roles of social entrepreneurial self-efficacy and perceived desirability in the link between social capital and social entrepreneurial intention is also investigated in this study.

\section{Literature Review}

Recently, a significant amount of research has typically been interested in discussing what is included and excluded in the notion of social entrepreneurship (Canestrino et al., 2020). However, the available researches about social entrepreneurship illustrate the lack of the consistency in both definitions and focused objects. The existing overlap between and among separated levels of analysis such as studies of individuals (micro level), studies of organizations and processes (meso level), and extended studies of the economic, political and societal context (macro level) is emphasized. Also, the main existing contributions are more theoretically based than empirically grounded (Cukier et al., 2011).

Perceived desirability has been examined in-depth in the prevailing literature and employed in model formulations related to entrepreneurial intention (Păunescu et al., 2018). Perceived desirability is seen as the value that reflect alternative wants and wishes at a pre-decisional stage of decision-making process (Gollwitzer, 1996). In the entrepreneurship literature, perceived desirability is defined as the personal attractiveness of creating a business, that includes both intrapersonal and extrapersonal effects (Shapero, 1982); it is also understood as willingness, anxiety and enthusiasm to run one's own business (Fellnhofer, 2018; Peterman \& Kennedy, 2003). Some studies show that perceived desirability plays the important role in shaping entrepreneurial intention (Krueger et al., 2000). Thus, perceived desirability regarding social entrepreneurship might have the influence on social entrepreneurial intention in the context of Vietnam, and the following hypothesis is proposed to examine this relationship.

H1: Perceived desirability has a positive effect on social entrepreneurial intention. 
Social capital also has a positive effect on social entrepreneurial intention (Ernst, 2011). Social capital is not only known as a key capacity for developing communities, but also a vital determinant for enhancing sustainable development and strengthening quality of life (Zaremohzzabieh et al., 2019). Social capital is hence examined valuable to creation and success of social enterprise (Newman \& Dale, 2005). Moreover, social capital is not only likely to augment the cognitive and visible assets of entrepreneurs, but it also contributes to information, collaborative bonding, trust, and some another resources among members of social networks (Adler \& Kwon, 2002). However, it is difficult to explain clearly and undisputedly the meaning of social capital (Dolfsma \& Dannreuther, 2003; Foley \& Edwards, 1997). Social capital refers to close supports of family and friends involved in the emergence of entrepreneurs (Davidsson \& Honig, 2003), but it also reflects the value embedded in the social relationships of both individuals and collectives (Adler \& Kwon, 2002). So, social capital can be defined as the totality of both actual and potential support resources implanted within, that is available and drives from the social networks and relationships (Nahapiet \& Ghoshal, 1998). In addition, the effects of social capital on entrepreneurial intention has been investigated in some prior studies (Doanh \& Bernat, 2019; Liñán \& Santos, 2007; De Carolis et al., 2009; Schlaegel \& Koenig, 2014).

Social capital describes such results as entrepreneurial and financial benefits which an individual can receive by his or her relationships with others, family and relation (Alder \& Kwon, 2002; Pitt et al., 2006). The formation of social capital requires people to invest time and other recourse to build and maintain the acquire capital from social network (Hanafizadeh et al., 2012). In the country like Vietnam, where normative support is often seen as the critical restriction for running one's own business, social capital could be more influential on self-efficacy, perceived desirability and entrepreneurial intention. Thus, the following hypotheses are proposed to test the impacts social capital on social entrepreneurial self-efficacy, perceived desirability and social entrepreneurial intention.

H2: Social capital has a positive effect on social entrepreneurial intention

H3: Social capital has a positive effect on perceived desirability.

H4: Social capital has a positive effect on social entrepreneurial self-efficacy

However, several studies show that entrepreneurial efficacy has been determined as an important factor and the best predictor to explain a person' entrepreneurial intention and success (Tsai et al., 2014; Krueger et al., 2000; Liñán,
2008). Previous studies had contributed substantially to the entrepreneurial literature; however, questions regarding the effect of entrepreneurial self-efficacy on the entrepreneurial intention are still not fully answered (Tsai et al., 2014). Personal beliefs in his/her ability to perform a typical behaviour have effects on perceived behavioral control and attitudes toward behavior, thus influencing the intention to carry out this behavior (Ajzen, 1991). In the social entrepreneurship, the role of social entrepreneurial efficacy on perceived desirability and intention to run social business should be explored.

H5: Social entrepreneurial self-efficacy has a positive effect on perceived desirability

H6: Social entrepreneurial self-efficacy has a positive effect on social entrepreneurial intention.

Besides, perceived desirability can mediate the relationships between social entrepreneurial self-efficacy, social capital and social entrepreneurial intention. Also, the link between social capital and social entrepreneurial intention can be mediated by social entrepreneurial selfefficacy. Thus, the hypotheses are proposed as following.

H7: The link between social capital and social entrepreneurial intention is mediated by perceived desirability

H8: The link between social entrepreneurial selfefficacy and social entrepreneurial intention is mediated by perceived desirability

H9: The link between social capital and social entrepreneurial intention is mediated by social entrepreneurial self-efficacy.

Figure 1 shows the conceptual model of this study.

\section{Research Methods and Materials}

\subsection{Survey and Sample}

The survey questionnaire consists of two sections, built on the purpose of the study, theoretical background and hypotheses. Firstly, the questions are designed to allow respondents to give their viewpoint regarding social entrepreneurial self-efficacy, social capital, perceived desirability, and social entrepreneurial intention. Secondly, demographic questions are designed to collect respondents' information such as gender, age, fields of study, year of study, and type of current professional (working) activities.

The questionnaire surveys were distributed directly to university and college students in Vietnam. Undergraduate students at universities and colleges in Vietnam are 


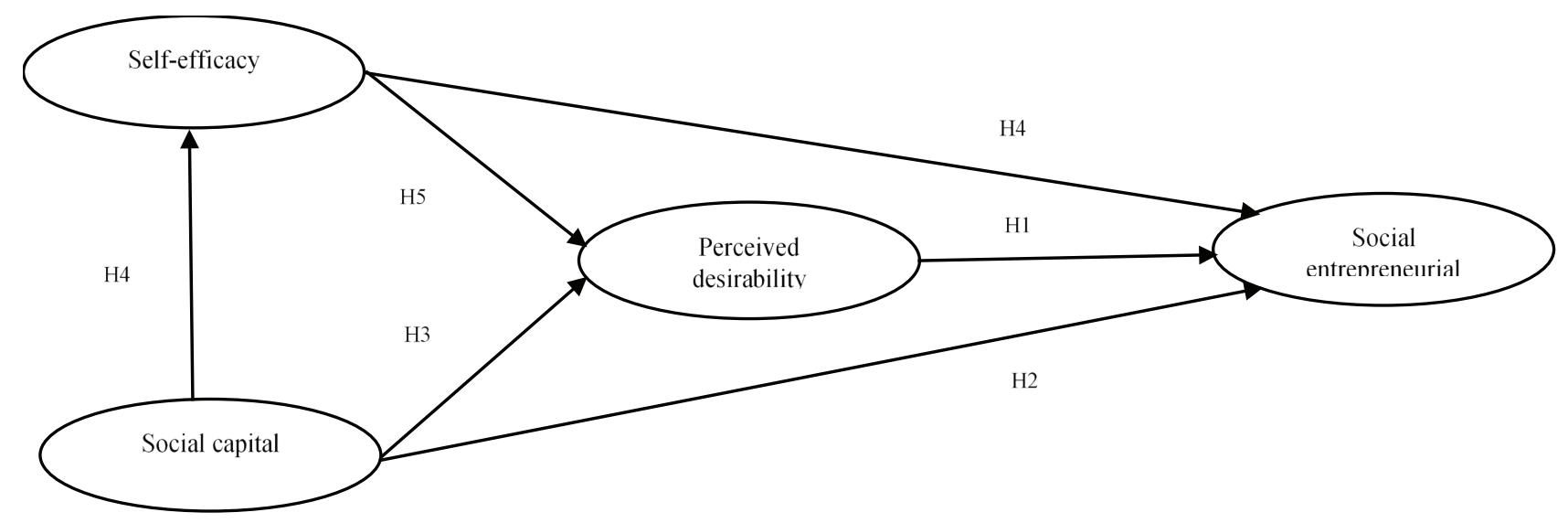

Figure 1: Conceptual Framework

Table 1: Descriptive statistics of sample demographics

\begin{tabular}{|c|c|c|c|c|c|}
\hline \multicolumn{2}{|c|}{ Demographic information } & Frequency & Percent & Mean & Standard Deviation \\
\hline \multirow[t]{3}{*}{ Age } & From 18 to $19 y e a r s$ old & 49 & 17 & \multirow[t]{3}{*}{1,8408} & \multirow[t]{3}{*}{0,393} \\
\hline & From 20 to 2 years old & 237 & 82 & & \\
\hline & Over 24 yearsold & 3 & 1 & & \\
\hline \multirow[t]{2}{*}{ Gender } & Male & 115 & 39.8 & \multirow[t]{2}{*}{1,6021} & \multirow[t]{2}{*}{0,490} \\
\hline & Female & 174 & 60.2 & & \\
\hline \multirow[t]{2}{*}{ Field of study } & Economic & 218 & 75.4 & \multirow[t]{2}{*}{1,2448} & \multirow[t]{2}{*}{0,430} \\
\hline & Non-Economic & 71 & 24.6 & & \\
\hline \multirow[t]{4}{*}{ Years of study } & First year & 12 & 4.1 & \multirow[t]{4}{*}{2.8858} & \multirow[t]{4}{*}{0,695} \\
\hline & Second year & 52 & 18 & & \\
\hline & Third year & 182 & 63 & & \\
\hline & Final year & 43 & 14.9 & & \\
\hline \multirow{4}{*}{$\begin{array}{l}\text { Type of current } \\
\text { professional } \\
\text { (working) } \\
\text { activities }\end{array}$} & Only studying & 90 & 31,1 & \multirow[t]{4}{*}{2,1938} & \multirow[t]{4}{*}{1,101} \\
\hline & $\begin{array}{l}\text { Studying and working for a } \\
\text { company }\end{array}$ & 115 & 39,8 & & \\
\hline & $\begin{array}{l}\text { Studying and running own } \\
\text { business }\end{array}$ & 22 & 7,6 & & \\
\hline & Studying and looking for a job & 62 & 21,5 & & \\
\hline
\end{tabular}

chosen as the sample in our research. Liñán \& Chen (2009) state that samples of students are rather popular in entrepreneurship research (Autio et al., 2001; Krueger et al. 2000). Reynolds et al. (2012) also emphasize that undergraduate students have the highest intention to start a business. Although approximately 300 questionnaires were distributed to students at universities/colleges in Vietnam, only 289 questionnaires were fully completed. Demographic information of respondents is illustrated in Table 1.
Table 1 show that most respondents are from 20 to 24 years old, accounting for $82 \%$. Moreover, $60.2 \%$ of respondents are female, but $75.5 \%$ of them are studying the field related to economics. The percentage of students, who are studying in the third year, account for $63 \%$, following by second and final year student ( $18 \%$ and $14.9 \%$, respectively). The study also indicates that $39.8 \%$ of students are studying and working for a firm, and just $7.6 \%$ of them are studying and running own business. 


\subsection{Scales and Analytic Approach}

All scales used in our study were adapted from the previous studies, including social capital (Baughn et al., 2006), perceived desirability (Yousaf et al., 2014), social entrepreneurial self-efficacy (Liñán \& Chen (2009), and social entrepreneurial intention (Liñán \& Chen, 2009). A seven-point Likert scale was employed where 1 presented "strongly disagree) and 7 represented "strongly agree".

A meta-analytic path analysis is employed to explore the effect of social capital on social entrepreneurial intention as well as the mediating role of perceived feasibility, social entrepreneurial self-efficacy in the link between social capital and social entrepreneurial self-efficacy. In particularly, structural equation modeling (SEM) was used to test the hypothesized relationships and the analysis process consists of three major steps. Firstly, Cronbach's alpha and explorative factor analysis (EFA) are implemented to assess the reliability of variables. Secondly, confirmatory factor analysis (CFA) is used to examine the empirical validity of the research model and each scales (variables) in this research model. Finally, the structural equation modeling
(SEM) was then employed to estimate path coefficients for each proposed relationship in the conceptual framework. In addition, the statistical analysis has been performed using SPSS 23.0 and AMOS 23.0 software.

\section{Results}

\subsection{Validity and Reliability}

According to the results from Table 2, Cronbach's alpha of all variables ranges from 0.793 to 0.910 . Thus, all variables' Cronbach's alpha values are acceptable for testing reliability of the scale. After analysing the reliability of scales by Cronbach's alpha, 16 items are used in the exploratory factor analysis (EFA). The first results of testing the validity of scales by the exploratory factor analysis shows that $\mathrm{KMO}=0.828$, Sig. (Bartlett's Test $)=0.000<0.005$, Initial eigenvalues $=69.275>50 \%$.

In order to examine measurement validity, the authors performed the confirmatory factor analysis (CFA) by using AMOS 23.0 (Hair et al., 1988). The results generally have shown a good level of fit for the measurement models.

Table 2: The results of exploratory factor analysis (EFA)

\begin{tabular}{|c|c|c|c|c|c|c|}
\hline \multirow{2}{*}{ Variables } & \multirow{2}{*}{ Items } & \multirow{2}{*}{$\begin{array}{l}\text { Cronbach's } \\
\text { Alpha }\end{array}$} & \multicolumn{4}{|c|}{ Component } \\
\hline & & & 1 & 2 & 3 & 4 \\
\hline \multirow{5}{*}{$\begin{array}{l}\text { Social capital } \\
\text { (SC) } \\
\alpha=0.910\end{array}$} & SC1 & 0.896 & 0.828 & & & \\
\hline & $\mathrm{SC} 2$ & 0.895 & 0.795 & & & \\
\hline & SC3 & 0.882 & 0.873 & & & \\
\hline & SC4 & 0.876 & 0.878 & & & \\
\hline & SC5 & 0.901 & 0.776 & & & \\
\hline \multirow{4}{*}{$\begin{array}{l}\text { Perceived } \\
\text { desirability } \\
\alpha=0.801\end{array}$} & PD1 & 0.795 & & 0.563 & & \\
\hline & PD2 & 0.738 & & 0.801 & & \\
\hline & PD3 & 0.703 & & 0.862 & & \\
\hline & PD4 & 0.760 & & 0.773 & & \\
\hline \multirow{3}{*}{$\begin{array}{l}\text { social } \\
\text { entrepreneurial } \\
\text { self-efficacy } \\
\alpha=0.793\end{array}$} & ESE1 & 0.683 & & & 0.790 & \\
\hline & ESE2 & 0.831 & & & 0.783 & \\
\hline & ESE3 & 0.755 & & & 0.657 & \\
\hline \multirow{4}{*}{$\begin{array}{l}\text { Social } \\
\text { entrepreneurial } \\
\text { intention } \\
\alpha=0.843\end{array}$} & SEI1 & 0.843 & & & & 0.697 \\
\hline & SEI2 & 0.793 & & & & 0.813 \\
\hline & SEI3 & 0.778 & & & & 0.822 \\
\hline & SEI4 & 0.786 & & & & 0.816 \\
\hline \multicolumn{3}{|c|}{$\begin{array}{l}\text { Kaiser-Meyer-Olkin Measure of Sampling Adequacy } \\
\text { (KMO) }\end{array}$} & \multicolumn{4}{|c|}{0.828} \\
\hline \multicolumn{3}{|c|}{ Sig. of Bartlett's Test of Sphericity } & \multicolumn{4}{|c|}{0.000} \\
\hline \multicolumn{3}{|l|}{ Cumulative \% } & \multicolumn{4}{|c|}{69.275} \\
\hline
\end{tabular}


After assessing each scale, the full measurement model was analysed in Figure 2. The results of CFA represented a reasonably good level of fit: $\chi^{2}=223.239, \mathrm{df}=88 ; \mathrm{p}=$ 0.000. CMIN/df $=2.537<0.5$ (Kettinger et al., 1995), $\mathrm{CFI}=0.943>0.9, \mathrm{GFI}=0.914>0.9, \mathrm{TLI}=0.922>0.9$ (Bentler \& Bonnett, 1980), RMSEA $=0.073<0.08$ (Awang, 2012). Also, standardized regression weights of all items are higher than $0.5(\lambda>0.5)$. Thus, the convergent validity is determined at all scales.

In addition, Table 3 shows the results of testing the discriminant validity between variables. The correlation of each couple of variables (r) and standard deviation (SE) are different to $1(\mathrm{P}$-value $=0.000<0.005)($ Gerbing \& Anderson. 1998). Thus, the discriminant validity between variables is proved.

Table 4 illustrates the results of testing the measurement validity by confirmatory factor analysis. The results represent standardized regression weights $(\lambda)$, composite reliability (CR) and average variance extracted (AVE) of all variables. Jöreskog (1971) consider that composite reliability of scales

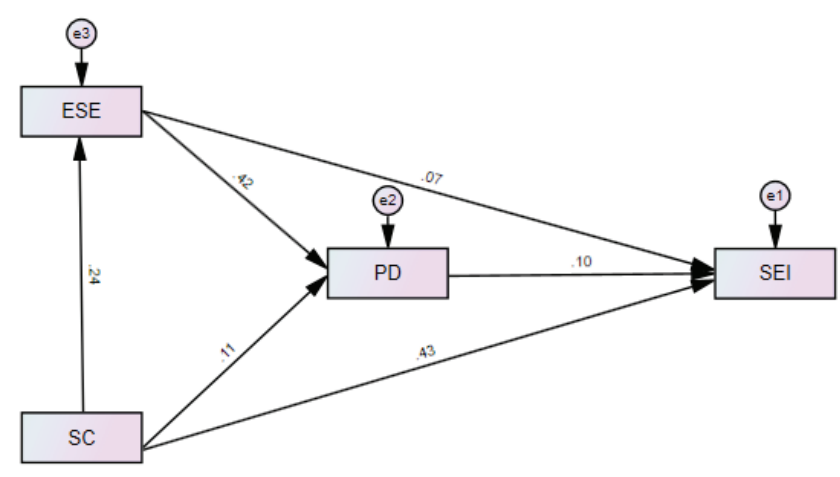

Figure 2: The results of structural analyses (unstandardized estimates)

Table 3: The results of testing the discriminant validity between variables $(\mathrm{N}=289)$

\begin{tabular}{|l|c|c|c|c|c|}
\hline Correlations & $\mathbf{r}$ & $\mathbf{r}^{2}$ & $\mathbf{S E}$ & $\mathbf{C R}$ & P-value \\
\hline $\mathrm{SC} \leftrightarrow \mathrm{PD}$ & 0.220 & 0.048 & 0.021 & 37.640 & $* * *$ \\
\hline $\mathrm{SC} \leftrightarrow \mathrm{ESE}$ & 0.295 & 0.087 & 0.020 & 34.733 & $* * *$ \\
\hline $\mathrm{SC} \leftrightarrow \mathrm{SEI}$ & 0.489 & 0.239 & 0.019 & 27.577 & $* * *$ \\
\hline $\mathrm{PD} \mathrm{ESE}$ & 0.505 & 0.255 & 0.018 & 26.997 & $* * *$ \\
\hline $\mathrm{PD} \mathrm{SEI}$ & 0.218 & 0.048 & 0.021 & 37.719 & $* * *$ \\
\hline $\mathrm{ESE} \leftrightarrow \mathrm{SEI}$ & 0.446 & 0.199 & 0.019 & 29.138 & $* * *$ \\
\hline
\end{tabular}

Note: $r$ : correlation; $R^{2}$ : Coefficient of Determination; SE: Standard Deviation; CR: Critical Ratios; ${ }^{* *}<0.001$. should be higher than $0.5\left(\rho^{\mathrm{c}}>0.5\right)$, also the average variance extracted should be higher than $0.5\left(\rho^{v c}>0.5\right)$ (Fornell \& Larcker, 1981). Thus, the composite reliability (CR) and average variance extracted (AVE) of all scales reached the reasonable levels.

\subsection{Structural and Meta-Analytic Path Analyses}

The overall fit statistics of the model without the control variables illustrated an acceptable level of fit: $\chi^{2}=223.239$, $\mathrm{df}=88 ; \mathrm{p}=0.000, \mathrm{CFI}=0.943>0.9, \mathrm{GFI}=0.914>0.0$, $\mathrm{TLI}=0.922>0.9$, RMSEA $=0.073<0,08$. So, the original model was used to test the hypothesized relationships (see Figure 2).

Table 5 shows that all hypothesized paths are statistically significant, but the significant level is different. In particular, social capital has the strongest effects on social entrepreneurial intention $(\beta=0.601 ; \mathrm{p}$-value $<0.001)$ ( $\mathrm{H} 2$ is supported), followed by perceived desirability $(\beta=$ $0.102 ; \mathrm{p}$-value $=0.006<0.01)(\mathrm{H} 1$ is supported $)$ and social entrepreneurial self-efficacy $(\beta=0.072 ; p$-value $=0.03<$ 0.01) (H6 is supported). The study also exhibits that social entrepreneurial self-efficacy affects significantly perceived desirability $(\beta=0.419 ; \mathrm{p}$-value $<0.000)$ (H5 is supported). Besides social entrepreneurial intention, social capital also has the dramatic effect on social entrepreneurial selfefficacy ( $\beta=0.239 ; p$-value $<0.000)$ (H4 is supported), and perceived desirability $(\beta=0.110 ; \mathrm{p}$-value $=0.002<0.01)$ (H4 is supported).

In order to investigate the effect of factors on social entrepreneurial intention, besides considering the direct relationship, this study also discovers the indirect effect of variables on entrepreneurial intention. In terms of the statistical method, researching the mediating impacts is considered as testing the effect of independent variable on dependent variable through mediators. In case of being a large sample, we can use the Sobel test to investigate these

Table 4: The results of testing the measurement validity by confirmatory factor analysis $(\mathrm{N}=289)$

\begin{tabular}{|l|c|c|l|}
\hline \multicolumn{1}{|c|}{ Scales } & \multicolumn{1}{c|}{$\boldsymbol{\lambda}$} & \multicolumn{1}{c|}{ CR } & \multicolumn{1}{c|}{ AVE } \\
\hline Social capital (SC) & 0.825 & 0.914 & 0.682 \\
\hline Perceived desirability (PD) & 0.727 & 0.819 & 0.534 \\
\hline $\begin{array}{l}\text { Social Entrepreneurial Self- } \\
\text { efficacy (ESE) }\end{array}$ & 0.676 & 0.721 & 0.521 \\
\hline $\begin{array}{l}\text { Social Entrepreneurial } \\
\text { Intention (SEI) }\end{array}$ & 0.735 & 0.832 & 0.564 \\
\hline $\begin{array}{l}\text { Note: } \lambda \text { : Standardized Regression Weights; CR: Composite } \\
\text { reliability; AVE: Average Variance Extracted. }\end{array}$ \\
\hline
\end{tabular}


Table 5: The results of the path analysis among variables with standardized regression weights

\begin{tabular}{|l|c|c|c|c|c|}
\hline \multicolumn{1}{|c|}{ Relationships } & Estimate & S.E & C.R & P-value & Results \\
\hline $\mathrm{SC} \rightarrow \mathrm{ESE}$ & 0.239 & 0.040 & 4.169 & ${ }^{* * *}$ & Significant \\
\hline $\mathrm{ESE} \rightarrow \mathrm{PD}$ & 0.419 & 0.066 & 7.763 & ${ }^{* * *}$ & Significant \\
\hline $\mathrm{SC} \rightarrow \mathrm{PD}$ & 0.110 & 0.046 & 4.037 & 0.002 & Significant \\
\hline $\mathrm{ESE} \rightarrow \mathrm{SEI}$ & 0.072 & 0.079 & 6.220 & 0.003 & Significant \\
\hline $\mathrm{SC} \rightarrow \mathrm{SEI}$ & 0.423 & 0.050 & 8.125 & ${ }^{* * *}$ & Significant \\
\hline $\mathrm{PD} \rightarrow \mathrm{SEI}$ & 0.102 & 0.064 & 7.773 & 0.006 & Significant \\
\hline
\end{tabular}

Note: ${ }^{* *}<0.001$; S.E: Standard Deviation; C.R: Critical Ratios. SC: Social capital; ESE: Social entrepreneurial self-efficacy; PD: Perceived desirability; SEI: Social entrepreneurial intention

Table 6: The results of bootstrapping in testing the mediators

\begin{tabular}{|l|l|c|c|c|c|c|c|}
\hline & \multicolumn{1}{|c|}{ Path } & SC $\rightarrow$ ESE & SC $\rightarrow$ PD & SC $\rightarrow$ SEI & ESE $\rightarrow$ PD & ESE $\rightarrow$ SEI & PD $\rightarrow$ SEI \\
\hline \multirow{2}{*}{$\begin{array}{l}\text { Standardized direct } \\
\text { effect }\end{array}$} & Estimate & 0.239 & 0.110 & 0.432 & 0.419 & 0.071 & 0.102 \\
\cline { 2 - 8 } & P-value & 0.000 & 0.002 & 0.000 & 0.000 & 0.003 & 0.006 \\
\hline \multirow{2}{*}{$\begin{array}{l}\text { Standardized indirect } \\
\text { effect }\end{array}$} & Estimate & & 0.100 & 0.038 & & 0.043 & \\
\cline { 2 - 8 } & P-value & & 0.030 & 0.019 & & 0.030 & \\
\hline \multirow{2}{*}{$\begin{array}{l}\text { Standardized total } \\
\text { effect }\end{array}$} & Estimate & 0.239 & 0.210 & 0.470 & 0.419 & 0.114 & 0.102 \\
\cline { 2 - 8 } & P-value & 0.045 & 0.031 & 0.002 & 0.001 & 0.002 & 0.003 \\
\hline
\end{tabular}

Note: SC: Social capital; ESE: Social entrepreneurial self-efficacy; PD: Perceived desirability; SEI: Social entrepreneurial intention

indirect effects (Sobel, 1986). However, Preacher and Hayes $(2008 \mathrm{a}, \mathrm{b})$ state that the bootstrapping method should be employed because it is more effective if using original data.

In our study, we apply bootstrapping methods to discover the mediating effect of social capital on entrepreneurial intention via social entrepreneurial self-efficacy and perceived desirability (see Table 6). The research results illustrate that the link between social capital and social entrepreneurial intention is mediated by social entrepreneurial self-efficacy and perceived desirability $\left(\beta_{\text {indirect SC-SEI }}=0.038 ; \mathrm{p}=0.019<\right.$ 0.05 ) (H7 and $\mathrm{H} 9$ are supported). Also, perceived desirability mediates the relationship between social entrepreneurial self-efficacy and intention $\left(\beta_{\text {indirect ESE-SEI }}=0.043 ; \mathrm{p}=0.030<\right.$ 0.05) (H7 and $\mathrm{H} 9$ are supported).

\section{Conclusions}

This research is expected to contribute to both entrepreneurship literature and practices, especially in social business venture. Firstly, social capital plays the important role in shaping social entrepreneurial self-efficacy, perceived desirability, and social entrepreneurial intention. So, in order to promote social entrepreneurship and innovation, policymakers and educators should find solutions to improve students' social capital. Students also should build social network by themselves, which is necessary for business venture in the future. Secondly, this study also shows that social entrepreneurial self-efficacy has a significant effect on perceived desirability and social entrepreneurial intention. So, the authors argue that external environment can play the important role in enhancing the students' selfefficacy. Therefore, universities should have to design policies to nurture students' self-efficacy. Finally, the social entrepreneurial self-efficacy and perceived desirability, not only affect directly social entrepreneurial intention, but they also play the mediating roles in the link between social capital and social entrepreneurial intention.

Further research should extend the model by testing the role the new variables, especially external environment such as education, perceived university supports, and culture, to contribute more to entrepreneurship literature. Also, further research should increase the size of sample as well as use randomly sample methods to increase the significant level.

\section{References}

Acs, Z. J., \&Audretsch, D. B. (2003). The International Handbook of Entrepreneurship. Dordrecht, Germany: Kluwer Academic Publishers 
Adler, P., \& Kwon, S. (2002). Social capital: prospects of a new concept. Academy of Management Review, 27(1), 17-40.

Agbim, K. C. (2019). Social networking and the family business performance: A conceptual consideration. Journal of Entrepreneurship, Management and Innovation, 15(1), 83-122.

Ajzen, I. (1991). The theory of planned behaviour. Organizational Behaviour and Human Decision Processes, 50(2), 179-211.

Anh, T.P.T., \& Harald, V.K. (2016). A conceptual model of social entrepreneurial intention based on the social cognitive career theory. Asia Pacific Journal of Innovation and Entrepreneurship, 10(1), 17-38.

Arregle, T.L., Hitt, M., Sirmon, D., \& Very, P. (2007). The development of organizational social capital: Attributes of family firms. Journal of Management Studies, 44(1), 73-95.

Alvord, S.H., Brown, L.D. \& Letts, C.W. (2004). Social entrepreneurship and societal transformation: an exploratory study. The Journal of Applied Behavioral Science, 40(2), 260-282.

Austin, J., Stevenson, H., \& Wei-Skillern, J. (2006). Social and commercial entrepreneurship: Same, different or both? Entrepreneurship, Theory and Practice, 30(1), 1-22.

Autio, E., H. Keeley, R., Klofsten, M., Parker, G. C., \& Hay, M. (2001). Entrepreneurial intent among students in Scandinavia and in the USA. Enterprise and Innovation Management Studies, 2, 145-160.

Awang, Z. (2012). Structural Equation Modeling using Amos Graphic. Penerbit Universiti Teknologi MARA, Malaysia.

Baughn, C. C., Cao, J.S.R., Le, L.T.M, Lim, V. A. \& Neupert, K.E (2006). Normative, Social and Cognitive predictors of entrepreneurial interest in China, Vietnam and the Philippines. Journal of Development Entrepreneurship, 11(1), 57-77.

Bentler, P.M., \& Bonnet, D.G. (1980). Significance tests and goodness of fit in the analysis of covariance structures. Psychological Bulletin, 88, 588-606.

Bhagavatula, S., Elfring, T., van Tilburg, A., \& van de Bunt, G.G. (2010), How social and human capital influence opportunity recognition and resource mobilization in India's handloom industry, Journal of Business Venturing, 25, 245-260.

Bosma, N., \& Levie, J. (2010). Global entrepreneurship monitor: 2009 Global Report. Wellesley, MA: Babson College; Universidad Del Desarrollo, Reykjavik University.

Boyd, N.G., \& Vozikis, G.S. (1994). The Influence of Self-efficacy on the Development of Entrepreneurial Intentions and Actions. Entrepreneurship Theory and Practice, 18(4), 63-77.

Canestrino, R., Ćwiklicki, M., Magliocca, P., \& Pawelek, B. (2020). Understanding social entrepreneurship: A cultural perspective in business research. Journal of Business Research, 110, 132143.

Chandra, Y., \& Shang, L., (2017). Unpacking the biographical antecedents of the emergence of social enterprises: a narrative perspective. Voluntas [Online First]. https://link.springer.com/ article/10.1007/s11266-017-9860-2.
Chan, F. (2017). Social entrepreneurship as emancipatory work. Journal of Business Venturing, 32, 657-673.

Cukier, W., Trenholm, S., Carl, D., \& Gekas, G. (2011). Social entrepreneurship: A content analysis. Journal of Strategic Innovation and Sustainability, 7(1), 99-119.

Dacin, P. A., Dacin, M. T., \& Matear, M. (2010). Social entrepreneurship: Why we don't need a new theory and how we move forward from here. Academy of Management Perspectives, 24(3), 37-57. https://doi.org/10.5465/amp.24.3.37.

Davidsson, P., \& Honig, B. (2003). The role of social and human capital among nascent entrepreneurs. Journal of Business Venturing, 18, 301-331

De Carolis, D. M., Yang, Y., Deeds, D. L., \& Nelling, E. (2009). Weathering the storm: The benefit of resources to hightechnology ventures navigating adverse events. Strategic Entrepreneurship Journal, 3(2), 47-160.

Dees, J. G., \& Anderson, B. B. (2006). Framing a theory of social entrepreneurship: Building on two schools of practice and thought. Research on Social Entrepreneurship: Understanding and Contributing to an Emerging Field, Association for Research on Nonprofit Organizations and Voluntary Action (ARNOVA), ARNOVA Occasional Paper Series, 1(3), 39-66.

Doanh, D. C., \& Bernat, T. (2019). Factors related to the intention of starting a business: A study among Students in Vietnam. Problemy Zarzadzania - Management Issues, 17(6), 133-157. https://doi.org/10.7172/1644-9584.86.8

Dolfsma, W., \& Dannreuther, C. (2003). Subjects and boundaries: Contesting social capital-based policies, Journal of Economic Issues, 37(2), 405-413.

Durieux, M.B., \& Stebbins, R.A. (2010). Social Entrepreneurship for Dummies. Hoboken, NJ: Wiley.

Dwivedi, A., \& Weerawardena, J. (2018). Conceptualizing and operationalizing the social entrepreneurship construct. Journal of Business Research, 86, 32-40.

Ernst, K. (2011). Heart over mind-An empirical analysis of social entrepreneurial intention formation on the basis of the theory of planned behaviour. Unpublished dissertation, University Wuppertal, Germany.

Felício, J. A., Gonçalves, H. M., \& da Conceição Gonçalves, V. (2013). Social value and organizational performance in nonprofit social organizations: Social entrepreneurship, leadership, and socioeconomic context effects. Journal of Business Research, 66(10), 2139-2146. https://doi.org/10.1016/j. jbusres.2013.02.040.

Fellnhofer, K. (2018). Narratives boost entrepreneurial attitudes: Making an entrepreneurial career attractive? European Journal of Education, 53, 218-237.

Foley, M. W., \& Edwards, B. (1997). Editors' introduction escape from politics? Social theory and the social capital debate. American Behavioral Scientist, 40(5), 550-561.

Fornell, C., \& Larcker, D. F. (1981). Evaluating Structural Equation Models with Unobservable Variables and Measurement Error. Journal of Marketing Research, 18(1), 39-50. 
Gerbing, D.W., \& Anderson, J.C. (1988). An updated paradigm for scale development incorporating unidimensionality and its assessment. Journal of Marketing Research, 25(2), 186-192.

Gollwitzer, P. (1996). The volitional benefits of planning. In: Gollwitzer, P., Bargh, J., (Eds.), The Psychology of Action: Linking Cognition and Motivation to Behavior (pp. 287-312). New York, NY: Guilford.

Hanafizadeh, P., Hanafizadeh, M. R., \& Khodabakhshi, M. (2010). E-business deployment in Iranian IT firms: An empirical research on recommendations. International Journal of Value Chain Management, 14(1/2), 49-67.

Hair, J .F. J., Anderson, R. E., Tatham, R .L, \& Black, W. C., (1998). Multivariate Data Analysi, (5th ed.). Upper Saddle River, NJ: Prentice Hall.

Haugh, H. (2007). New strategies for a sustainable society: the growing contribution of social entrepreneurship. Business Ethics Quarterly, 17(4), 743-749. https://doi.org/10.5840/ beq20071747

Hartog, C., \& Hoogendoorn, B. (2011). Prevalence and determinants of social entrepreneurship at the macro-level (No. H201022). Netherlands: EIM Business and Policy Research.

Jöreskog, K.G. (1971). Simultaneous factor analysis in several populations. Psychometrika, 36, 409-426.

Johnson S. (2003). Literature Review of Social Entrepreneurship. New Academy Review, 2. Available at: https://www. researchgate.net/publication/246704544_Literature_Review_ Of_Social_Entrepreneurship.

Kedmenec, I., \& Strašek, S. (2017). Are some cultures more favourable for social entrepreneurship than others? Economic Research - Ekonomska istraživanja, 30(1), 1461-1476. https:// doi.org/10.1080/1331677X.2017.1355251.

Kettinger, W.J., Lee, C. C., \& Lee, S. (1995). Global measures of information service quality: A cross-national study. Decision Sciences, 26(5), 559-588.

Krueger, N. F., Reilly, M. D., \& Carsrud, A. L. (2000). Competing models of entrepreneurial intentions. Journal of Business Venturing, 15(5), 411-432.

Lee, W. S, \& Kim, B.Y. (2019). The Effects of Career Orientations on Entrepreneurial Satisfaction and Business Sustainability. Journal of Asian Finance, Economics and Business, 6(4), 235-248. https://doi.org/10.13106/jafeb.2019.vol6.no4.235

Liao, J., \& Welsch, H. (2005). Roles of social capital in venture creation: Key dimensions and research implications. Journal of Small Business Management. 43(4), 345-362.

Liñán, F., \& Santos, F. J. (2007). Does social capital affect entrepreneurial intentions? International Advances in Economic Research, 13(4), 443-453.

Liñán, F., Santos, F. J., \& Fernández, J. (2011). The influence of perceptions on potential entrepreneurs, International Entrepreneurship and Management Journal, 7(3), 373-390.

Liñán, F., \& Chen, Y. W. (2009). Development and Cross-Cultural Application of a Specific Instrument to Measure Entrepreneurial
Intentions. Entrepreneurship Theory and Practice, 33(3), 593-617.

Lu, H., \& Wang, J. (2018). Entrepreneurial Intention of Two Patterns of Planned Behaviour and Alertness: Empirical Evidence in China. Journal of Asian Finance, Economics and Business, 5(2), 63-72. https://doi.org/10.13106/jafeb.2018.vol5.no2.63

Luc, P.T. (2018). The Relationship between Perceived Access to Finance and Social Entrepreneurship Intentions among University Students in Vietnam. Journal of Asian Finance, Economics and Business, 5(1), 63-72. http://dx.doi. org/10.13106/jafeb.2018.vol5.no1.63

Nahapiet, J., \& Ghoshal, S. (1998), Social capital, intellectual capital, and the organizational advantage, Academy of Management Review, 23(2), 242-266.

Newman, L., \& Dale, A. (2005). Network structure, diversity, and proactive resilience building: A response to Tompkins and Adger. Ecology and Society, 10(1), 1-4.

Nicholls, A., \& Cho, A. H. (2006). Social entrepreneurship: The structuration of a field. In A. Nicholls (Ed.). Social entrepreneurship: New models of sustainable social change (pp. 99-118). New York: Oxford University Press.

Păunescu, C., Popescu, M.C., \& Duennweber, M. (2018). Factors determining desirability of entrepreneurship in Romani. Sustainability, 10(11), 3893. https://doi.org/10.3390/ su10113893

Peredo, A.M., \& McLean, M. (2005). Social entrepreneurship: a critical review of the concept. The Journal of World Business, 41(1), 56-65.

Peterman, N.E., \& Kennedy, J. (2003). Enterprise education: Influencing students' perceptions of entrepreneurship. Entrepreneurship: Theory and Practices, 28, 129-144.

Pitt, L., Merwe, R. D., Berthon, P., Salehi-Sangari, E., \& Barnes, B. R. (2006). Swedish BioTech SMEs: The veiled values in online networks. Technovation, 26(5-6), 553-560.

Preacher, K. J., \& Hayes, A. F. (2008a). Asymptotic and resampling strategies for assessing and comparing indirect effects in multiple mediator models. Behavior Research Methods, 40, 879-891.

Preacher, K. J., \& Hayes, A. F. (2008b). Contemporary approaches to assessing mediation in communication research. In: A. F. Hayes, M. D. Slater, \& L. B. Snyder(Eds.), The Sage sourcebook of advanced data analysis methods for communication research (pp. 13-54). Thousand Oaks, CA: Sage Publications.

Reynolds, P., Cox, L., \& Autio, E. (2012). Global Entrepreneurship Monitor: 2002. Executive Report. London, UK: Global Entrepreneurship Research Association. Available at: https:// www.gemconsortium.org/report/gem-2002-global-report

Rey-Martí, A., Ribeiro-Soriano, D., \& Palacios-Marqués, D. (2016). A bibliometric analysis of social entrepreneurship. Journal of Business Research, 69(5), 1651-1655.

Robinson, J.A. (2006). Navigating social and institutional barriers to markets: how social entrepreneurs identify and evaluate 
opportunities. In: Mair, J., Robinson, J.A. and Hockerts, K. (Eds), International Perspectives on social entrepreneurship (pp. 1-6). Houndsmills, England: Palgrave Macmillan.

Schlaegel, C., \& Koenig, M. (2014). Determinants of entrepreneurial intent: A meta-analytic test and integration of competing models. Entrepreneurship Theory and Practice, 38(2), 291-332.

Shane, S., \& Venkataraman. S. (2000). The promise of entrepreneurship as a field of research. Academy of Management Review. 25(1), 217-226.

Shapero A. (1982). Social Dimensions of Entrepreneurship. In: C. Kent, D. Sexton and K. Vesper (Eds.), The Encyclopedia of Entrepreneurship ( $p p$. 72-90). Englewood Cliffs, NJ: Prentice-Hall.

Sobel, M. E. (1986). Some new results on indirect effects and their standard errors in covariance structure models. In: S. Leinhart (Ed.), Sociological Methodology (pp. 159-186). San Francisco, CA: Jossey-Bass.

Thompson, B. (2002). What future quantitative social science research could look like: Confidence intervals for effect sizes. Educational Researcher, 31(3), 25-32.

Tsai, K. H., Chang, H.C., \& Peng, C.Y. (2014). Extending the link between entrepreneurial self-efficacy and intention: A moderated mediation model. International Entrepreneurship and Management Journal, 12, 445-463.
Vuković, K., Kedmenec, I., Postolov, K., Jovanovski, K., \& Korent. D. (2017). The role of bonding and bridging cognitive social capital in shaping entrepreneurial intention in transition economies. Management, 22(1), 1-33.

Welter, F., Baker, T., Audretsch, D.B., \& Gartner, W.B. (2017). Everyday entrepreneurship - a call for entrepreneurship research to embrace entrepreneurial diversity. Entrepreneurship: Theory \& Practices, 41(3), 311-321.

Yunus, M. (2008). Creating a world without poverty: Social business and the future of capitalism. New York, NY: Public Affairs.

Yousaf, U., Shamim, A., Siddiqui, H., \& Raina, M. (2015). Studying the influence of entrepreneurial attributes, subjective norms and perceived desirability on entrepreneurial intentions. Journal of Entrepreneurship in Emerging Economics, 7(1), 23-34.

Zahra, S. A., Gedajlovic, E., Neubaum, D. O., \& Shulman, J. M. (2009). A typology of social entrepreneurs: Motives, search processes and ethical challenges. Journal of Business Venturing, 24(5), 519-532.

Zahra, S.A., \& Wright, M. (2016). Understanding the social role of entrepreneurship. Journal of Management Studies, 53(4), 610-629.

Zaremohzzabieh, Z., Ahrari, S., Krauss, S. E., Samah, A. A., Meng, L.W., \& Ariffin, Z. (2019). Predicting social entrepreneurial intention: A meta-analytic path analysis based on the theory of planned behavior. Journal of Business Research, 96, 264-276. 